\title{
TECHNO-MORPHOLOGICAL FEATURES OF ITEMS MADE OF ANTLER FROM THE SITE NEAR THE VILLAGE OF MICHNIEVIČY (NORTH-WESTERN BELARUS)
}

(C) 2019

Malyutina Anna Andreevna, junior researcher of Experimental-Traceology Laboratory Institute of History of Material Culture of the Russian Academy of Sciences (Saint-Petersburg, Russian Federation) Vashanov Aleksandr Nikolaevich, researcher of Archeology of Primitive Society Department

Tkacheva Mariya Ivanovna, researcher of Conservation and Use of the Archaeological Heritage Department Institute of History of the National Academy of Sciences of Belarus (Minsk, Republic of Belarus)

Tkach Evgenia Sergeevna, candidate of historical sciences, junior researcher of Paleolithic Department Institute of History of Material Culture of the Russian Academy of Sciences (Saint-Petersburg, Russian Federation)

Abstract. The paper presents the results of a techno-morphological analysis of items made of antler obtained as a result of the collections from the 1960s-1990s from the site near the village of Michnievičy Smorgon District of the Grodno Region (north-western Belarus). Currently, more than 100 artifacts are known from this site, as well as a large number of fauna residues with no visible traces of processing. Radiocarbon dating was obtained for some categories of products, which link them to 9-2 thousand BC. The largest part of the collection refers to the period of the Mesolithic - Neolithic. At the first stage of work, the most expressive and numerous group of artifacts made of horn (24 exemplars), stored in the fonds of the Institute of History of the National Academy of Sciences of Belarus, was selected for a techno-morphological analysis. The degree of preservation of the external surface of objects is relatively good, which made it possible to analyze macro-traces related to the technology of manufacturing various categories of products, on the basis of which a process flow was proposed - from the selection of raw materials to the finished product. The analysis of the technological traces recorded on the products allowed us to highlight the differences in the manufacturing processes of the oldest tools. In addition, on the basis of the macro signs of utilitarian wear, preliminary observations on the functional using of objects were obtained. According to technological and morphological features, the whole of the analyzed material was divided into conditional categories of instruments with a selected «heel» and without it. The presence or absence of this element, apparently, influenced the method of using objects in various household situations.

Keywords: Mesolithic; Early Neolithic; Belarus; Vilija; Neman; Smarhon quarries; Michnievičy; site; quarry; horn products; traceological analysis; choice of raw materials; processing technology; primary processing; preform; secondary processing; setting; macrotraces; microtraces; function; typology; category; experiment.

\section{ЭНЕОЛИТИЧЕСКОЕ ПОСЕЛЕНИЕ И МОГИЛЬНИК ВАСИЛЬЕВСКИЙ КОРДОН 27: СВИДЕТЕЛЬСТВА ОХОТЫ И РЫБНОЙ ЛОВЛИ (ИССЛЕДОВАНИЯ 2016-2018 ГОДОВ, ПРЕДВАРИТЕЛЬНАЯ ПУБЛИКАЦИЯ)}

(C) 2019

Смольянинов Роман Викторович, кандидат исторических наук, заведующий кабинетом археологии и этнологии

Юркина Елизавета Сергеевна, студент института истории, права и общественных наук Липецкий государственный педагогический университет имени П.П. Семенова-Тян-Шанского (2. Липеияк, Российская Федерация)

Яниш Евгения Юрьевна, кандидат биологических наук, младший научный сотрудник отдела мониторинга и охраны животного мира Институт зоологии им. И.И. Шмальгаузена НАН Украинь (г. Киев, Украина)

Желудков Андрей Сергеевич, научный сотрудник

Шеменев Сергей Викторович, научный сотрудник

Соловьев Андрей Владимирович, научный сотрудник

Липецкая региональная научная общественная организаџия «Археологические исследования» (2. Липеик, Российская Федераџия)

Аннотаичия. Обнаруженный в 2008 году А.А. Клюкойтем памятник археологии Васильевский Кордон 27 исследовался в 2016-2018 гг. В раскопе общей площадью 195 м² удалось выявить шесть древних сооружений и четыре погребения. Было обнаружено большое количество энеолитической керамики: среднестоговской и волосовской культур, посуда ксизовского типа. Обращает на себя внимание наличие большого количества находок, свидетельствующих об охоте и рыбной ловле на памятнике. Сопровождающий кремнёвый инвентарь представлен орудиями, имеющими отношение как к хозяйственной деятельности, так и к охотничьему вооружению, с преобладанием последних. В хозяйственных сооружениях, погребениях и культурном слое обнаружено 68 каменных наконечников стрел и дротиков. Также выявлено 2248 остатков животного происхождения. Из них 1389 - кости млекопитающих, 595 - птиц, 61 кость рептилии и 138 фрагментов раковин моллюсков. На памятнике впервые для Верхнего Подонья зафиксировано присутствие животноводства, при 
этом птицеводство отсутствовало. Тем не менее наличие в материалах костей диких видов млекопитающих, птиц, рыб и черепах подтверждает значение охоты и рыбалки как основного (но уже не единственного) источника пищи на поселении. При этом из кости изготовлены только четыре орудия охоты: острия и гарпуны по два обломка. Стоит отметить интересный факт - наличие рыболовных керамических грузиков для сетей, выточенных из стенок разбитых сосудов. Археологическая коллекция памятника Васильевский Кордон 27 относится преимущественно к эпохе позднего энеолита и датируется 3-2 четвертью IV тыс. до н.э.

Ключевые слова: наконечник; кость; керамика; поселение; домашнее животное; кремень; постройка; погребение; гарпун; рептилия; моллюск; птица; животное; млекопитающее; охота; рыбалка; собирательство; лесостепь; кварцит; Верхний Дон; типологический анализ; энеолит.

Поселение и могильник Васильевский Кордон 27 открыт в 2008 году А.А. Клюкойтем [1]. В последующем памятник исследовался в 2016-2018 гг. [2-4]. Он находится на пойменном останце в правобережье p. Воронеж у с. Преображеновка Добровского района Липецкой области (рис. 1: 1). В раскопе площадью $195 \mathrm{м}^{2}$ удалось выявить шесть древних сооружений и четыре погребения. Погребения одновременны среднестоговскому слою поселения. Ранее нами было высказано мнение о том, что первое погребение могильника, возможно, относится к волосовской культуре и имеет более позднюю хронологию. Погребение датировано по кости животного из заполнения могилы - $3592 \pm 55$ ВР (2133-1772 calBC) и по кости самого погребенного - $3775 \pm 60$ ВР (1876-1510 calBC) [5, c. 184]. Подобная ситуация характерна для всех известных в лесостепном Подонье могильниках среднестоговской культуры, расположенных на площадках поселений. В раскопе было обнаружено большое количество энеолитической керамики преимущественно среднестоговской культуры (195 сосудов, выделенных по венчикам), встречается также посуда ксизовского типа (55 сосудов) и единичные керамические материалы волосовской культуры (?) [6]. Керамика эпохи бронзы представлена единичными фрагментами катакомбной и фатьяновской культур. Столь яркие материалы позволяют сделать реконструкции отдельных аспектов хозяйственной жизни древнего населения. Обращает на себя внимание наличие огромного количество находок, прямо свидетельствующих об охоте и рыбной ловле.

На территории Верхнего Дона чрезвычайно редки поселения эпохи энеолита, с которых получены представительные археозоологические коллекции. На реке Воронеж подобные артефакты есть только на стоянках Васильевский Кордон 17 (далее ВК 17), Васильевский Кордон 27 (далее ВК 27), Доброе 9, Доброе 7, на Дону - Ксизово 6. В данной работе проанализированы археозоологические материалы памятника ВК 27 за 2016-2017 гг. и частично за 2018 г. Общий объем выборки составил 2248 остатков животного происхождения.

Из них 1389 - кости млекопитающих, 595 - птиц, 61 кость рептилии и 142 фрагмента раковин моллюсков. Сохранность материала - 3-4 балла по пятибалльной шкале [7], неопределимые остатки составили $63,1 \%$. Материалы определены по стандартной методике [8; 9].

Для выявления достоверного соотношения всех встречавшихся в добыче и рационе местных жителей в исследуемый период времени видов считается достаточной выборка из 400 определенных до вида костей [7]. В данном случае 386 костей млекопитающих определены до вида, что уже позволяет высчитать основные соотношения. Так, в материале палео- зоологической коллекции выявлены 10 видов млекопитающих - лось (Alces alces), бобр (Casper fiber), медведь бурый (Ursus arctos), лисица (Vulpes vulpes), зубр европейский (Bison bonasus), кабан (Sus scrofa), олень благородный (Cervus elaphus), косуля европейская (Capreolus capreolus), а также бык домашний (Bos taurus) и собака домашняя (Canis familiaris). Под вопросом остаются кости, принадлежащие представителям рода Лошадиные (Equus). Изначально остатки двух особей нами были определены как лесной тарпан (Equus gmelini), на сегодня ввиду сложной дифференциации тарпана и лошади домашней (Equus caballus) все найденные кости лошадей с памятника ВК 27 мы описываем только до рода. Кроме того, выявлены 3 кости, с большой долей вероятности принадлежавшие мелкому рогатому скоту. Так как фрагменты исследованных костей не несут морфологических признаков, позволяющих их стопроцентно отнести к домашним видам, мы их указываем под вопросом. Для окончательного вывода о присутствии домашней лошади, а также МРС на памятнике необходимы дальнейшие исследования. Кроме того, в раскопе выявлены кости мышевидных грызунов. Кости домашних животных встречаются единично и составляют лишь 2,0\%. При этом на памятнике ВК 17 (исследовано $353 \mathrm{~m}^{2}$ ) [10-13], расположенном на расстоянии около 200 м от Васильевского Кордона 27, домашние животные обнаружены не были. Мы используем археозоологическую выборку с памятника ВК 17 в целях сравнения и дополнения данных для эпохи энеолита по видовому составу и соотношению их, так как по археологическим данным и радиоуглеродным датам памятники практически синхронны (погрешность возможна, так как в культурном слое памятника встречены единичные материалы эпохи бронзы) (табл. 1).

В археозоологических материалах с ВК 27, по сравнению с ВК 17, отсутствуют кости рыси, меньшее количество костей медведей (для получения более полной картины мы приводим не проценты, а данные по абсолютному количеству костей). Если на ВК 17 были найдены 195 костей медведя бурого, то на ВК 27 - только 13. Бобра по абсолютному количеству костей было добыто на обоих памятниках в равном количестве (следует учесть, что на данный момент исследована разная площадь памятников), тогда как лося несколько меньше (237 костей на ВК 27 и 291 - на ВК 17). В добыче на ВК 27 отсутствуют такие виды, как барсук (Meles meles), куница (Martes sp. да и все куньи в целом) и волк (Canis lupus). Возможно, ВК 27 все же чуть более молодой памятник, и на момент функционирования уже сказалось влияние человека на охотничьи виды. Этим можно объяснить и резкое уменьшение количества медведей в культурном слое памятника ВК 27. 
Полученные дикие виды относятся к трем группам охотничьей добычи, которые традиционно выделяют по экономической значимости [14]. К мясной добыче относятся лось, кабан, зубр, олень благородный, косуля и тарпан, ко второй группе (виды мелкого и среднего размера, добываемые ради мяса и шкурок) - бобр. К третьей группе (хищники, добытые ради шкур и, возможно, для получения лекарственных препаратов и/или совершения обрядов) - медведь и лисица.
Также получена коллекция костей птиц, определимых до рода и до вида. Они составили $35,7 \%$, при этом в охотничьей добыче доминирует кряква (Anas platyrhynchos) - 21,5\% (от всех костей птиц), на втором месте чирки (чирок-трескунок и чирок-свистунок - ввиду большой схожести костей у этих двух видов и значительной фрагментированности остеологических остатков объединены нами в одну группу «чирки») - $14,2 \%$.
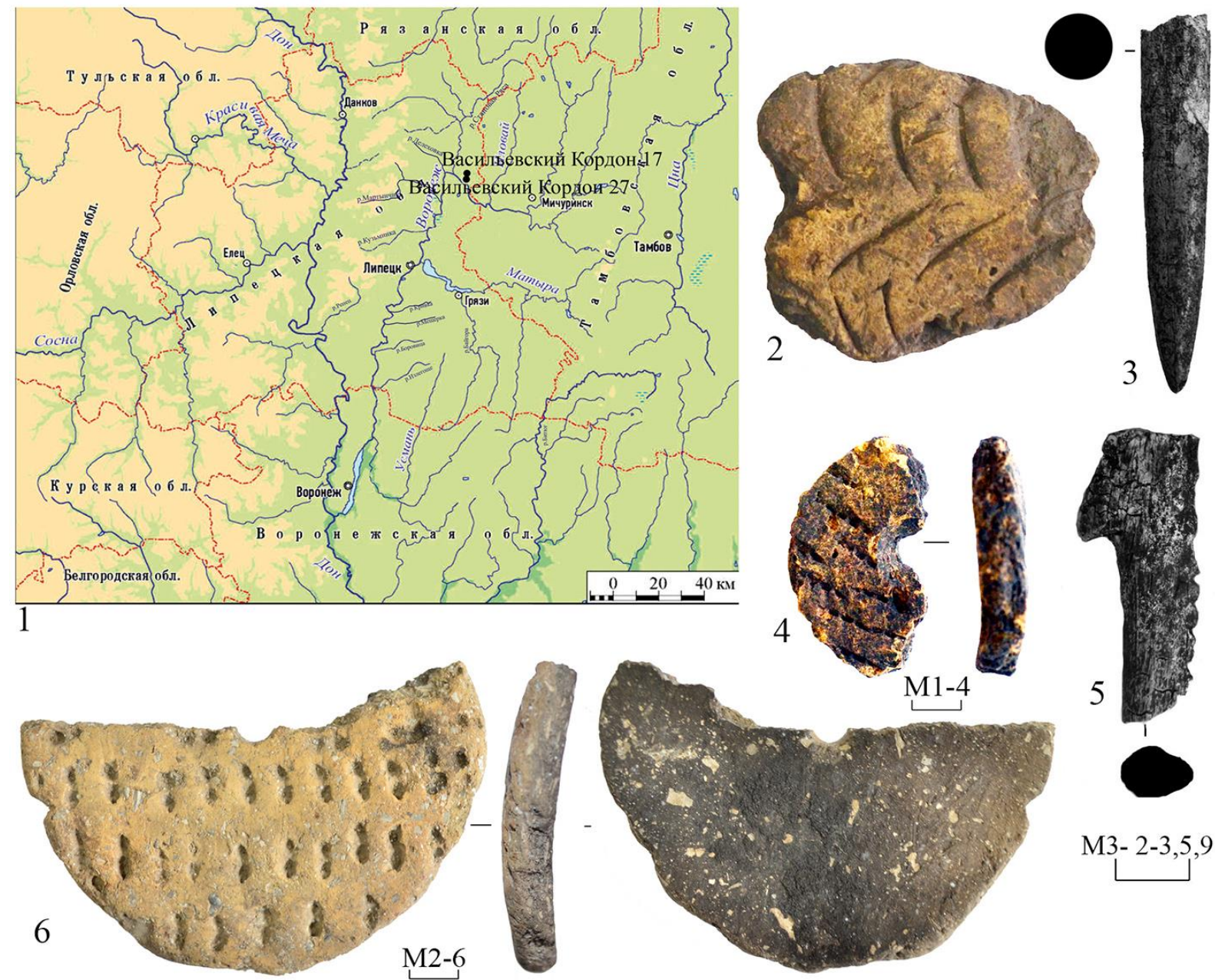

M3- 2-3,5,9
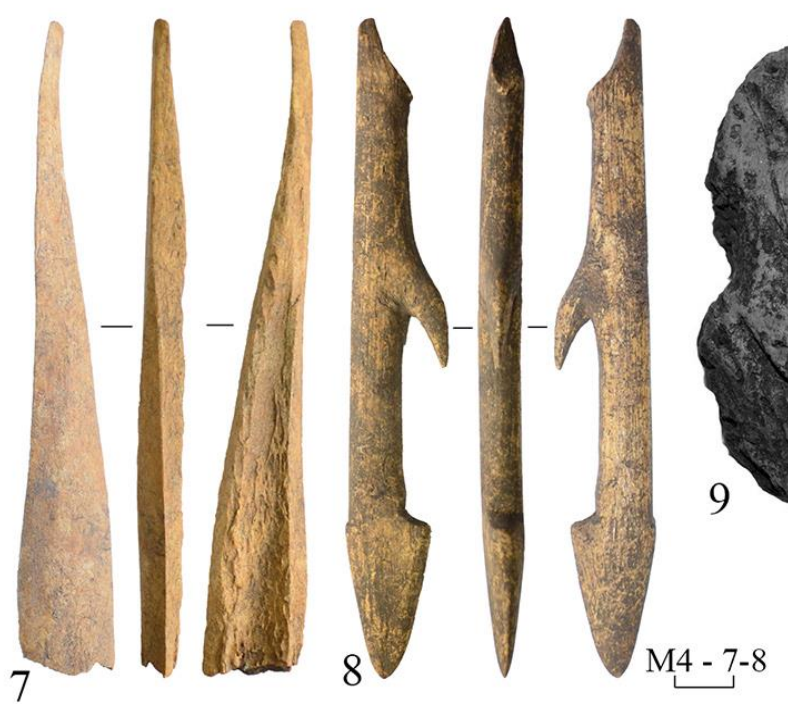

Рисунок 1 - Поселение и могильник Васильевский Кордон 27.

1 - Местоположение памятников, упоминаемых в статье, на карте Центрального Черноземья; 2, 4, 6, 9-керамические грузики; 3, 5, 7, 8- костяные орудия 
Смольянинов Р.В., Юркина Е.С., Яниш Е.Ю., Желудков А.С., Шеменев С.В., Соловьев А.В. BK 27

Таблица 1 - Видовой состав и процентное соотношение видов остатков животного происхождения ВК 17 и

\begin{tabular}{|l|c|c|}
\hline \multicolumn{1}{|c|}{ Вид } & $\begin{array}{c}\text { Васильевский Кордон 17, } \\
\%\end{array}$ & $\begin{array}{c}\text { Васильевский Кордон 27, } \\
\text { (1,3 }\end{array}$ \\
\hline Лось & 41,4 & 60,6 \\
\hline Бобр & 0,4 & - \\
\hline Рысь & 27,7 & 3,4 \\
\hline Медведь бурый & 5,3 & 0,5 \\
\hline Лиса & 0,1 & 2 \\
\hline Зубр & - & 4,4 \\
\hline Грызун & 10,5 & 6,4 \\
\hline Кабан & - & 1,8 \\
\hline Бык домашний & - & 2 \\
\hline Семейство Лошадиные & - & 0,3 \\
\hline Собака домашняя & - & 0,8 \\
\hline МРС (?) & - & 0,3 \\
\hline Олень благородный & 0,3 & 0,5 \\
\hline Тарпан & - & 0,3 \\
\hline Косуля & 2,7 & - \\
\hline Барсук & 1 & - \\
\hline Куница & 0,9 & - \\
\hline Волк & 0,4 & 100 \\
\hline Семейство Куньи & 100 & \\
\hline & & - \\
\hline
\end{tabular}

Все выявленные кости рептилий принадлежат одному виду - черепахе болотной (Emys orbicularis), общее количество остатков с ВК 27 - 80 экземпляров, тогда как в материале с ВК 17 были найдены 59 фрагментов панцирей и костей черепахи. Наличие данного вида указывает на то, что поселение точно функционировало в теплое время года, т.к. начиная с осени, в зимний период и ранней весной поймать черепаху болотную практически невозможно, в связи с тем что данный вид в холодное время года зарывается в ил и зимует на дне водоемов. Наиболее вероятно, что черепаха активно использовалась в пищу местным населением, а часть фрагментов панциря несет следы обработки (подобные фрагменты встречены на обоих памятниках).

О рыбной ловле жителями энеолитического поселения ВК 27 ярко свидетельствуют находки костей рыб. Видовой состав их частично совпадает с памятником ВК 17. Присутствуют сом (Silurus glanis), щука (Esox lucius) и судак (рис. 5: 20). Кости на обоих памятниках сохраняются очень плохо. Не исключено, что большая часть костей рыб просто не сохранилась. О наличии сетевого рыболовства ярко свидетельствует наличие в культурном слое четырех глиняных дисков - керамических грузиков с пропилами по двум краям (рис. 1: 2, 4, 6, 9). Они изготовлены из стенок разбитых сосудов. На стоянке ВК 17 подобных грузов обнаружено более 60 .

Костяной инвентарь ВК 27 представлен двумя гарпунами (рис. 1: 5, 8) и двумя остриями (рис. 1: 3, $7)$, которые могли применяться как на охоте, так и в рыбной ловле.

О доминирующей роли охоты говорит наличие большого количества разных видов каменных наконечников стрел и дротиков (рис. 2-5). За три года исследований памятника ВК 27 всего было выявлено 68 экземпляров, часть из которых представлена об- ломками. 3 наконечника были в погребении, 33 - в постройках и 32 - в культурном слое.

К дротикам и их заготовкам можно отнести 11 наконечников. Целых из них - пять, два из которых изготовлены из высококачественного мелового кремня черного цвета. Оба они ромбовидной формы, с двумя выделяющимися шипами, у одного - в нижней трети, а у другого - в верхней трети изделия. Край насада закруглен на обоих экземплярах, однако он был слегка отколот на одном (рис. 2: 1, 4). Третий целый дротик также представлен ромбовидной формой с двумя выделяющимися шипами в средней части изделия и черешком - «пуговкой» (рис. 2: 5). Четвертый наконечник дротика ромбической формы с закругленным насадом без выделенных шипов (рис. 2: 8). Пятый дротик треугольной формы с широким черешком и резко выделенными шипами (рис. 2: 9). Все целые экземпляры обработаны уплощающей ретушью.

Два фрагмента дротиков представлены средними частями, по которым невозможно определить форму изделия (рис. 2: 3, 7). Еще один фрагмент дротика из желтого валунного кремня подромбической формы с уплощенным срезом черешка (рис. 2: 2). Также в коллекции имеется три заготовки дротика (рис. 2: 6, 10-11).

С опорой на типологию, разработанную Н.Н. Гуриной $[15$, с. 64], в рассматриваемой коллекции наконечники стрел подразделяются по форме пера на:

- ромбической формы с выделенным черешком и с шипами в средней части изделия (рис. 3: 1-6). Всего таковых шесть, один из которых выполнен из кварцита, а остальные из кремня. Среди них есть обработанные как уплощающей ретушью, так и приостряющей;

- ромбической формы с усеченным основанием без выделенных шипов (рис. 3: 10, 14). Всего их две единицы - из серого валунного кремня и кварцита; 

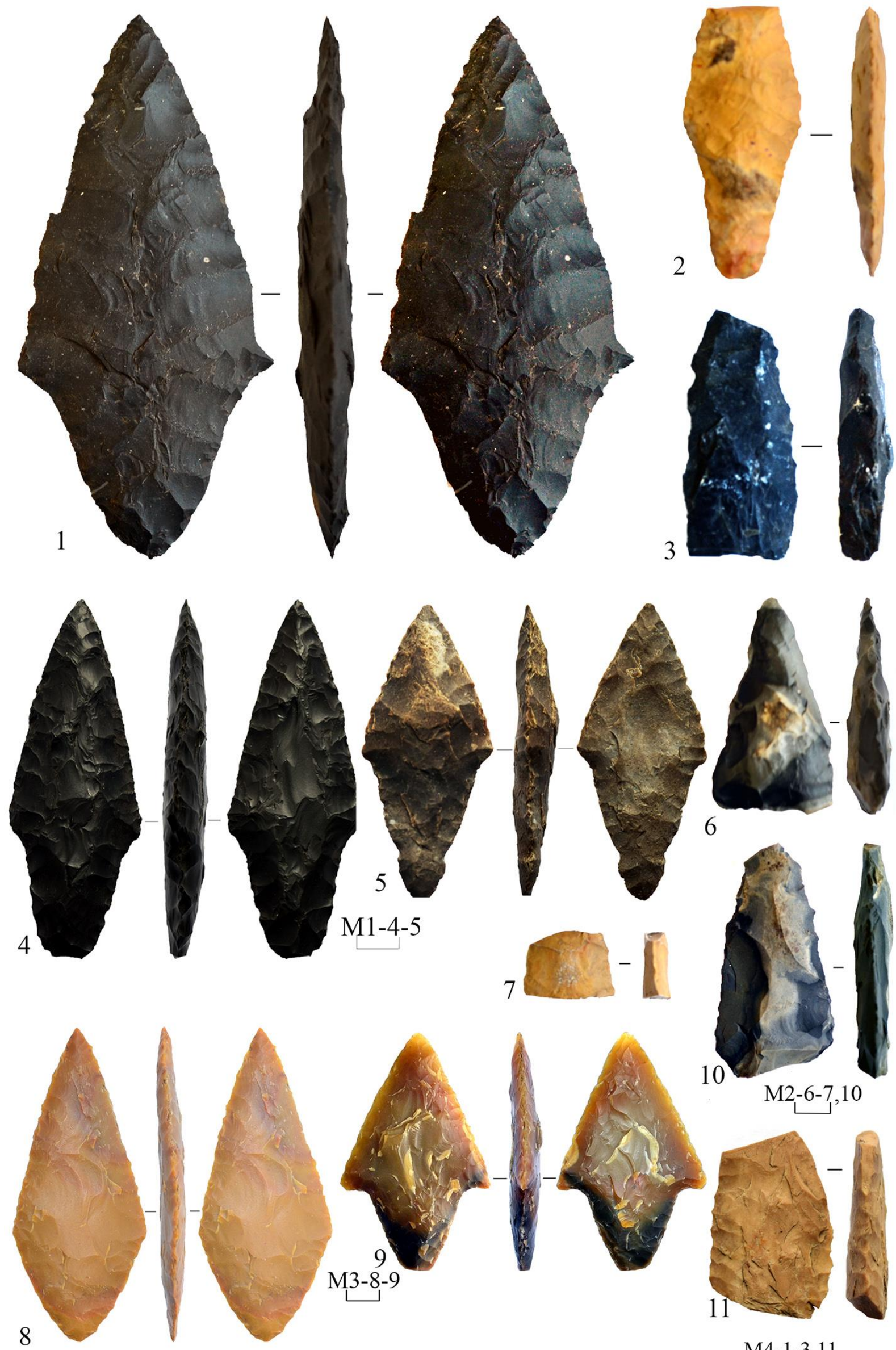

M3-8-9

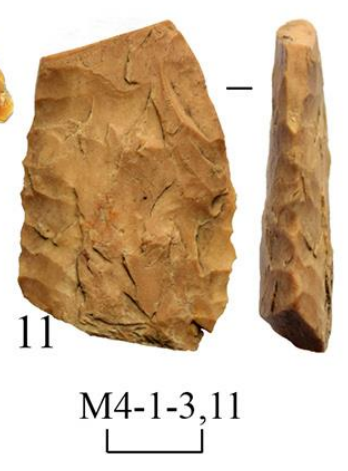

Рисунок 2 - Поселение и могильник Васильевский Кордон 27. Наконечники дротиков. 1, 2, 4, 6-7, 11 - наконечники из построек; 3, 5, 8-10- наконечники из культурного слоя 


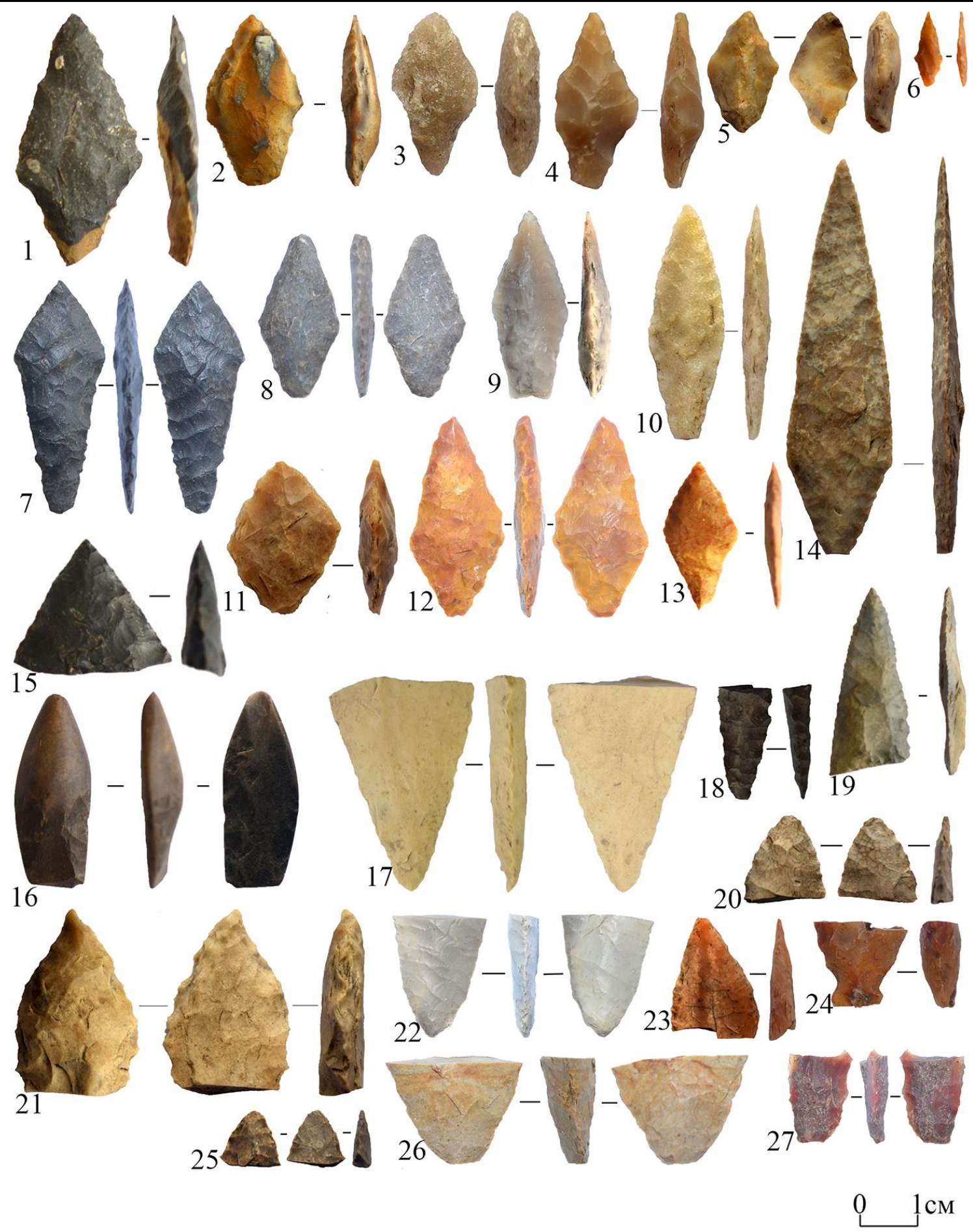

Рисунок 3 - Поселение и могильник Васильевский Кордон 27. Наконечники стрел ромбического типа. Обломки наконечников. 4, 8, 13- наконечники из построек; 1-3, 5-7, 9-12, 14, 16- наконечники из культурного слоя; 15- наконечник из погребения. 17-27- обломки наконечников

- ромбовидной формы с ретушью без выделенных шипов, выявлено четыре экземпляра из кремня (рис. 3: 8,11-13);

- ромбической формы с небольшой выемкой в основании без выделенных шипов из серого валунного кремня (рис. 3: 9) и выраженными шипами с длинным закругленным черешком из черного мелового кремня (рис. 3: 7) - по одному экземпляру;

- иволистной формы, выявлено три экземпляра (рис. 4: 1-3) обработанные: уплощающей, приостряющей и струйчатой ретушью;

- лавролистной обоюдоострой формы, обработанные уплощающей ретушью, представлены четырьмя наконечниками (рис. 4: 4-5, 10-11);
- листовидной обоюдоострой формы. Выявлено два экземпляра (рис. 4: 6, 8): один из серого валунного, второй из черного мелового кремня, обработаны отжимной ретушью;

- лавролистной формы (рис. 4: 7, 9) с усеченным основанием. Обработаны по сохранившейся кромке уплощающей ретушью, обнаружено два экземпляра;

- треугольной формы с широким усеченным черешком и слабо выделенными шипами, выявлен один наконечник из серого валунного кремня с приостряющей ретушью (рис. 5: 1);

- треугольной формы с заостренным черешком и слабо выделенными шипам. Выявлено всего два (рис. 5: $3,7)$ : один из коричневого кремня, другой из кварцита; 
- треугольной формы с заостренным черешком и резко выраженными шипами. Выявлено два наконечника (рис. 5: 2, 5): один из коричневого валунного, а другой из черного мелового кремня;

- треугольной формы с широким черешком и резко выделенными шипами (рис. 5: 4, 6, 8-16). Они представлены девятью целыми и двумя фрагментами. С двух сторон все покрыты приостряющей ретушью;

- треугольной формой в единичном экземпляре, представлены одним кварцитовым наконечником с заостренным слабовыраженным черешком (рис. 5: 17) и одним кремнёвым обломком пера (рис. 5: 19);

- треугольной формой с небольшой выемкой в основании (рис. 5: 18). Последняя разновидность наконечников наиболее типична для среднестоговской культуры [16, с. 66]. Но, несмотря на то что на поселении ВК 27 и преобладает керамический материал данной культуры, находка такого вида наконечника единична.

Выпадает из общей типологии шлифованный наконечник из камня (рис. 3: 16). Порода не ясна. Насад его изготовлен методом обивки. С брюшка у острия сделан прошлифованный желобок, типа крово- стока. Данная находка нетипична для нашей территории, ближайших аналогий нам выявить не удалось.

Остальные десять наконечников представлены обломками. Распознать их форму не представляется возможным (рис. 3: 15, 17-27).

Вызывает затруднение точное определение одного экземпляра наконечника (рис. 3: 21). Судя по морфологическим признакам, изначально он был листовидной формы, но после слома переоформлен в проколку. Однако без трасологических исследований этот вывод имеет право на существование только в варианте рабочей гипотезы.

На памятнике не обнаружено характерных форм каменных наконечников стрел эпохи бронзы - треугольных с выемкой в основании, а керамика этого времени представлена единичными фрагментами. Мы считаем возможным, что комплекс кремнёвого вооружения памятника Васильевский Кордон 27 в своем подавляющем большинстве относится к эпохе энеолита и может быть датирован 3-2 четвертью IV тыс. до н.э. (calBC). Наличие типологической вариабельности среди данного типа орудий подразумевает дифференцированный подход в их применении, связанный, скорее всего, с различными видами объектов охоты [17].
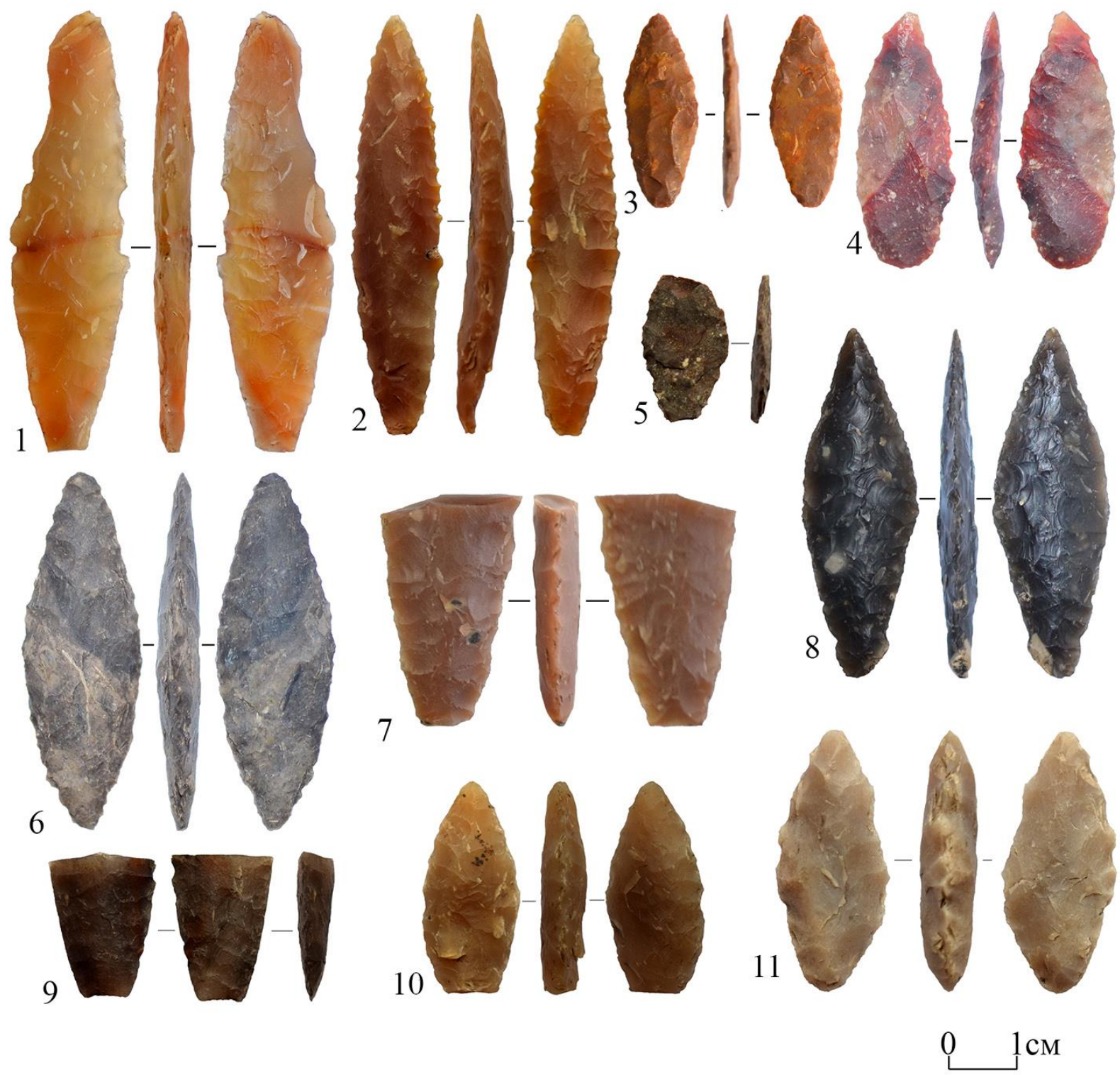

Рисунок 4 - Поселение и могильник Васильевский Кордон 27.

Наконечники стрел овального типа. 2, 5, 7, 9- наконечники из построек;

$1,3,4,8,10,11$ - наконечники из культурного слоя; 6- наконечник из погребения 

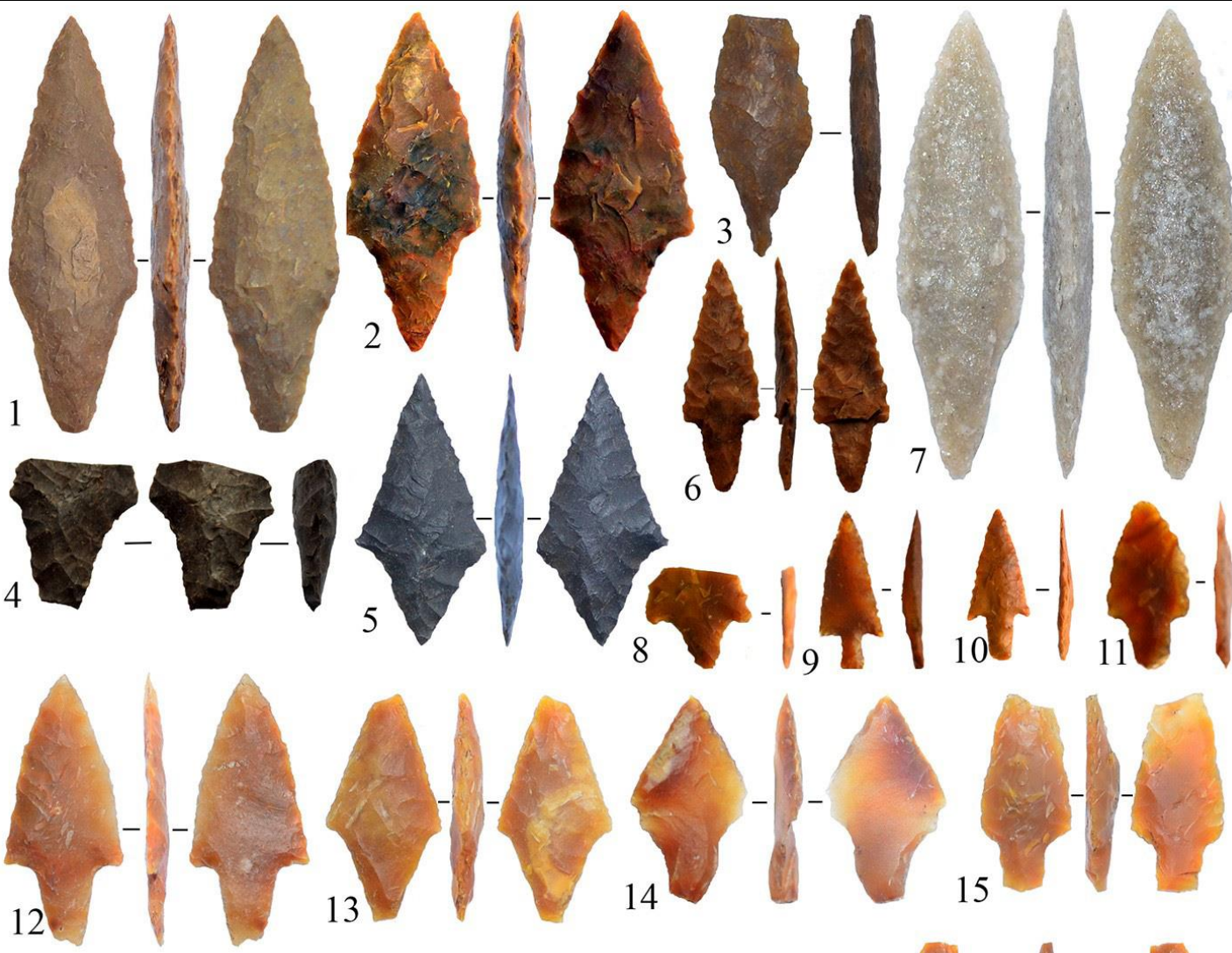

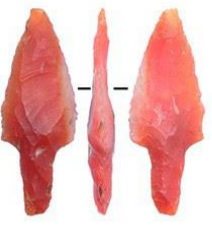

16
17

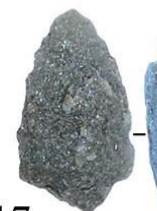

$\mathrm{BK}-17 \quad \square \mathrm{BK}-27$

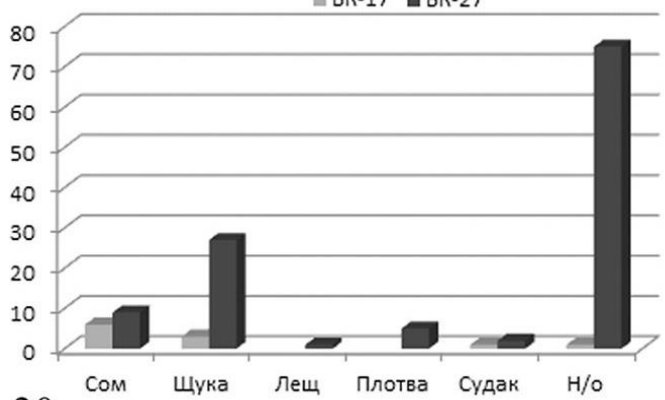

20
21
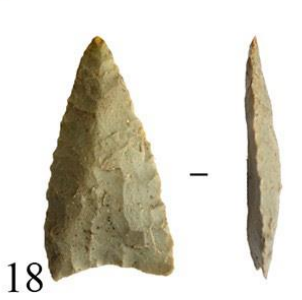

19
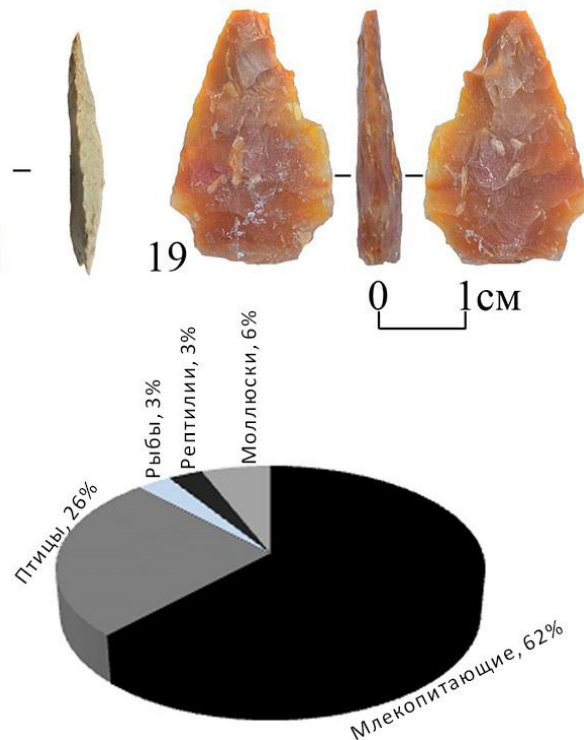

Рисунок 5 - Поселение и могильник Васильевский Кордон 27. Наконечники стрел треугольного типа.

$1-2,5,6,8,9,12,15,17$ - наконечники из построек; 3, 4, 10, 11, 13, 14, 16, 18, 19- наконечники из культурного слоя; 7- наконечник из погребения. 20- видовое соотношение рыб, Васильевский Кордон 17 и Васильевский Кордон 27 (абсолютное количество костей);

21 - процентное соотношение животных в добыче местного населения Васильевский Кордон 27

В целом, анализируя материалы памятника Васильевский Кордон 27, можно говорить, что в добыче местного населения доминировали млекопитающие. На втором месте были птицы (значительный процент из них - водоплавающие), рыбы и черепахи представлены в равных количествах, тогда как раковин моллюсков в процентном соотношении найдено столько же, сколько рыб и черепах вместе взятых (рис. 5: 21). Охота (и на млекопитающих, и на птиц) продолжала играть ведущую роль в обеспечении жителей поселения пищей. Рыбная ловля, как и охота на черепах, играла важную, но существенно меньшую роль. При этом собирательство, куда, вероятно, можно отнести добывание речных перловиц, все еще оставалось значительной составляющей в жизнеобеспечении местного населения. Очень несущественный процент домашних животных, возможно, указывает на зачаточное состояние животноводства в эпоху позднего энеолита в середине IV тыс. до н.э. на Верхнем Дону.

\section{Список литературы:}

1. Клюкойть А.А. Отчёт о разведочных исследованиях в Липецкой области в 2008 году // Архив Института археологии РАН (ИА РАН). Р-1. № 43232.

2. Смольянинов Р.В. Отчет о раскопках поселения Васильевский Кордон 27 в Добровском районе Липецкой области в 2016 году // Архив ИА РАН. Р-1. № 51398 . 
3. Шеменёв С.В. Отчет о раскопках поселения Васильевский Кордон 27 в Добровском районе Липецкой области в 2017 году.

4. Соловьев А.В. Отчет о раскопках поселения Васильевский Кордон 27 в Добровском районе Липецкой области в 2018 году.

5. Смольянинов Р.В. Волосовская культура на Верхнем Дону? // Труды V (XXI) Всероссийского археологического съезда в Барнауле - Белокурихе: сб. науч. тр. в 3 т. Барнаул: Изд-во Алт. ун-та, 2017. Т. 1. C. $181-185$.

6. Смольянинов Р.В., Желудков А.С., Яниш Е.Ю., Бессуднов А.Н., Куличков А.А., Юркина Е.С. Поселение Васильевский Кордон 27 на р. Воронеж. Материалы эпохи энеолита // Верхнедонской археологический сборник. Вып. 8. Липецк: ЛГПУ имени П.П. Семенова-Тян-Шанского, 2017. С. 225-240.

7. Антипина Е.Е. Археозоологические исследования: задачи, потенциальные возможности и реальные результаты // Новые археозоологические исследования в России. М.: Языки славянской культуры, 2003. C. 7-34.

8. Яниш Е.Ю., Смольянинов Р.В., Свиридов А.А. Животные в погребальных ритуалах населения Верхнего Дона эпох неолита и энеолита // Збірник праць зоологічного музею. № 46. Київ: ВД «Академперіодіка», 2015. С. 96-110.

9. Яніш Є.Ю., Смольянінов Р.В., Свірідов О.А. Результати археозоологічних досліджень неолітичної памятки Васильєвський Кордон 17, тварини в поховальних ритуалах // Інтерпретація арїеологічних джерел: здобутки та виклики: мат-ли наукової конференції молодих вчених. Київ: Стародавній світ, 2017. С. 35-36.

10. Свиридов А.А. Отчет о раскопках поселения Васильевский Кордон 17 в Добровском районе Ли- пецкой области в 2012 году // Архив ИА РАН. Р-1. № 41458.

11. Смольянинов Р.В. Отчет о раскопках поселения Васильевский Кордон 17 в Добровском районе Липецкой области в 2013 году // Архив ИА РАН. Р-1. № 41335 .

12. Смольянинов Р.В. Отчет о раскопках поселения Васильевский Кордон 17 в Добровском районе Липецкой области в 2014 году // Архив ИА РАН. Р-1. № 46375 .

13. Смольянинов Р.В. Отчет о раскопках поселения Васильевский Кордон 17 в Добровском районе Липецкой области в 2015 году // Архив ИА РАН. Р-1. № 45326.

14. Антипина Е.Е. Переяславль Рязанский, кремль, XVII век: остеологическая коллекция // Аналитические исследования лаборатории естественнонаучных методов / отв. ред. Е.Н. Черных. М.: Институт археологии Российской академии наук, 2011. С. 204-213.

15. Гурина Н.Н. Опыт первичной классификации кремневых наконечников стрел // Орудия каменного века / отв. ред. Д.Я. Телегин. Киев: Наукова Думка, 1978. С. $57-70$.

16. Телегін Д.Я. Середньостогівська культура епохи міді. К.: Наукова думка, 1973. 172 с.

17. Загорская И.А. Рыболовство и морской промысел в каменном веке на территории Латвии // Рыболовство и морской промысел в эпоху мезолита раннего металла в лесной и лесостепной зоне Восточной Европы / ред. Н.Н. Гурина. Л.: Наука, 1991. C. 39-64.

Статья публикуется при поддержке гранта РФФИ проект 18-49-480004 р_а «Поселение Доброе 9 в системе ранненеолитических древностей лесостепного Подонья" и гранта Фонда президентских грантов проект 19-2-018793.

\section{THE ENEOLITHIQUE SETTLEMENT AND BURIAL SITE VASILYEVSKIY KORDON 27: EVIDENCE OF HUNTING AND FISHING (EXCAVATIONS 2016-2018, PRELIMINARY PUBLICATION)}

(C) 2019

Smolyaninov Roman Viktorovich, candidate of historical sciences, head of Archeology and Ethnology Office

Yurkina Elizaveta Sergeevna, student of Institute of History, Law and Social Sciences

Lipetsk State Pedagogical P. Semenov-Tyan-Shansky University (Lipetsk, Russian Federation)

Yanish Yevgeniia Yurievna, candidate of biological sciences,

junior researcher of Animal Monitoring and Conservation Department

I.I. Schmalhausen Institute of Zoology of National Academy of Sciences of Ukraine (Kiev, Ukraine)

Zheludkov Andrey Sergeevich, researcher

Shemeniov Sergey Viktorovich, researcher

Soloviev Andrey Vladimirovich, researcher

Lipetsk Regional Scientific Public Organization «Archaeological Research» (Lipetsk, Russian Federation)

Abstract. The settlement and grave field Vasilyevskiy Kordon 27 was discovered by A.A. Klukoit in 2008 and it was investigated from 2016 to 2018. In the excavation within the area of 195 sq. m. six ancient buildings and four burials were identified. A large number of Eneolithique ceramics of the Srednestogovskaya and Volosovskaya culture as well as Ksizovski type vessels were discovered. A huge number of finds testify to the hunting and fishing on the monument. The accompanying flint inventory is represented by tools related to both economic activity and hunting weapons, with the latter predominating. In the outbuildings, burials and cultural layer 68 stone arrowheads and darts were found. 2245 residues of animal origin were also revealed. There are 1386 mammalian bones, 595 birds, 61 reptile bones and 138 fragments of mollusk shells among them. It is interesting to note that there were ceramic fishing weights carved from the broken vessels. On the monument animal husbandry was noted for the Upper Don for the first time, while poultry farming was absent. Bones of wild species of mammals, birds, fish and turtles confirm the importance of hunting and fishing as the main (but not the only) source of food in the settlement. At the same time, only four hunting tools were made of bone: two edges and two fragments of harpoons. The archaeological collection of the settlement Vasilyevskiy Kordon 27 refers mainly to the late Eneolithic period and dates the 3-2 quarter of the IV Millennium BC.

Keywords: stone arrowheads; ceramics; settlement; domestic animals; flint; building; burial; harpoon; reptile; mollusk; bird; animal; mammal; hunting; fishing; gathering; forest-steppe; quartzite; Upper Don; typological analysis; Eneolithic. 